\title{
Reslizumab and Eosinophilic Asthma: One Step Closer to Precision Medicine?
}

\section{Gilda Varricchi',2, Gianenrico Senna ${ }^{3}$, Stefania Loffredo ${ }^{1,2}$, Diego Bagnasco ${ }^{4}$, Matteo Ferrando ${ }^{4}$ and Giorgio Walter Canonica ${ }^{5 *}$}

'Division of Clinical Immunology and Allergy, Department of Translational Medical Sciences, School of Medicine, University of Naples Federico II, Naples, Italy, ${ }^{2}$ Center for Basic and Clinical Immunology Research (CISI), University of Naples Federico II, Naples, Italy, ${ }^{3}$ Asthma Center and Allergy Unit, Verona University, General Hospital, Verona, Italy, ${ }^{4}$ Allergy and Respiratory Diseases, DIMI Department of Internal Medicine, IRCCS AOU San Martino-IST, University of Genova, Genova, Italy, ${ }^{5}$ Personalized Medicine Clinic Asthma and Allergy Humanitas Clinical and Research Center, Department of Biomedical Science, Humanitas University, Rozzano, Milano, Italy

Human eosinophils represent approximately $1 \%$ of peripheral blood leukocytes. However, these cells have the propensity to leave the blood stream and migrate into inflamed tissues. Eosinophilic inflammation is present in a significant proportion of patients with severe asthma. Asthma is a chronic inflammatory disorder that affects more than 315 million people worldwide, with 10\% having severe uncontrolled disease. Although the majority of patients can be efficiently treated, severe asthmatics continue to be uncontrolled and are at risk of exacerbations and even death. Interleukin-5 (IL-5) plays a fundamental role in eosinophil differentiation, maturation, activation and inhibition of apoptosis. Therefore, targeting IL-5 is an appealing approach to the treatment of patients with severe eosinophilic asthma. Reslizumab, a humanized anti-IL-5 monoclonal antibody, binds with high affinity to amino acids 89-92 of IL-5 that are critical for binding to IL-5 receptor $\alpha$. Two phase III studies have demonstrated that reslizumab administration in adult patients with severe asthma and eosinophilia ( $\geq 400$ cells $/ \mu \mathrm{L}$ ) improved lung function, asthma control, and symptoms. Thus, the use of blood eosinophils as a baseline biomarker could help to select patients with severe uncontrolled asthma who are likely to achieve benefits in asthma control with reslizumab. In conclusion, targeted therapy with reslizumab represents one step closer to precision medicine in patients with severe eosinophilic asthma.

\section{Keywords: anti-IL-5, asthma, eosinophils, interleukin-5, IL-5 receptor, reslizumab}

\section{INTRODUCTION}

Bronchial asthma is a chronic heterogeneous inflammatory disorder characterized by recurrent symptoms of reversible airflow obstruction, bronchial hyperresponsiveness, and airway inflammation $(1,2)$. It has been estimated that asthma affects more than 315 million people worldwide, with approximately $10 \%$ having severe or uncontrolled asthma $(3,4)$. In addition, the worldwide

\footnotetext{
Abbreviations: ACQ, asthma control questionnaire; AQLQ, asthma quality of life questionnaire; ECP, eosinophil cationic protein; EDN, eosinophil-derived neurotoxin; EPX, eosinophil peroxidase; FDA, Food and Drug Agency; $\mathrm{FEV}_{1}$, forced expiratory volume in the 1st second; GM-CSF, granulocyte-macrophage colony-stimulating factor; ICS, inhaled glucocorticoids; ILC, innate lymphoid cells; IL-5, interleukin-5; IL-3, interleukin-3; LABA, long-acting $\beta_{2}$-agonists; MBP, major basic protein; NK T cells, natural killer cells.
} 
prevalence of asthma continues to increase and is projected to reach more than 400 million by 2020 (5). Importantly, approximately 250,000 deaths can be attributed to asthma each year, making it a severe chronic lung disorder (6).

Asthma's manifestations can range from mild to very severe. The majority of patients can be efficiently treated with different drugs administered orally and/or by specific devices [e.g., inhaled glucocorticoids (ICS)]. Patients with severe asthma require treatment with high-dosage ICS or systemic glucocorticoids plus long-acting $\beta_{2}$-agonists (GINA, accessed 2016). However, inhaled and systemic glucocorticoids can have multiple local (e.g., dysphonia and candidiasis) and systemic side effects (e.g., cataracts, osteoporosis, and adrenal suppression).

Despite the effectiveness of these treatments for most asthmatics, many patients continue to be uncontrolled and are at risk for severe asthma exacerbations or even death. These patients experience a high disease burden including recurrent exacerbations and hospital admissions (7). Finally, the cost of asthma treatment increases with disease severity (8).

The old concept that asthma represents a single disease has been replaced with the belief that it instead represents a heterogeneous mix of overlapping disorders that result from the interplay between multiple environmental factors (e.g., allergens, superallergens, viral and bacterial infections, etc.) that act in concert with hundreds of susceptibility genes (9-13).

Recently, it has been proposed that asthma can be classified according to two major endotypes. Endotype is a disease subtype defined by a distinct functional or pathological mechanism (14-16). "Th2-high" asthma is characterized by increased levels of type 2 inflammation, mainly mediated by eosinophils, mast cells, Th2 cells, group 2 innate lymphoid cells (ILC2s), and IgEproducing B lymphocytes (1). Patients with Th2-high asthma have eosinophilia and other signs of type 2 inflammation. By contrast, "Th2-low" asthma is less well characterized and probably represents a mix of multiple endotypes involving subgroups of patients $(1,17,18)$.

Approximately $5-10 \%$ of asthmatic patients have severe asthma that is poorly controlled by drugs including high-dosage ICS and/or systemic glucocorticoids. The mechanisms of glucocorticoid subsensitivity/insensitivity in severe asthma are largely unknown (19). Several mechanisms have been proposed to explain glucocorticoid resistance of a subset of severe asthmatics (20-28). Glucocorticoid subsensitive asthmatic patients with eosinophilic are likely to benefit from anti-interleukin-5 (IL-5)/ IL-5R $\alpha$ therapies (19). As we move away from the traditional clinical description to include a multidimensional emphasis on cellular biology (endotypes and phenotypes), we increase our opportunity to provide targeted therapies, especially in more severe diseases (29). Accurate definition of asthma endotypes/ phenotypes is critical in selecting targets for therapies, providing basis for targeted treatment of asthma (30).

\section{EOSINOPHILS IN ASTHMA}

Approximately 5-10\% of asthmatic patients have severe asthma that is poorly controlled by drugs including high-dosage of ICS and/or systemic glucocorticoids. The mechanisms of glucocorticoid subsensitivity or insensitivity in severe asthma are largely unknown (19).

Eosinophilic inflammation is present in a significant proportion of patients with severe asthma (31) and is associated with exacerbations and decreased lung function (32). Moreover, progressive increase in sputum and blood eosinophils is accompanied with poor pharmacological asthma control (33).

There is compelling evidence that eosinophils and their mediators are critical effectors to severe eosinophilic asthma and eosinophilic granulomatosis with polyangiitis (EGPA) $(34,35)$. EGPA is a systemic vasculitis frequently occurring in patients with severe asthma and eosinophilia. EGPA patients often have severe respiratory involvement that requires treatment with oral glucocorticoids (36).

Due to their rarity (approximately 1\% of peripheral blood leukocytes), eosinophils have been erroneously neglected for decades (37). During the last years, researchers of immediate hypersensitivity appreciated that these cells represent repositories of a wide spectrum of pro-inflammatory mediators such as several cationic proteins (major basic protein; eosinophil cationic protein; eosinophil peroxidase; and eosinophil-derived neurotoxin), cytokines/chemokines, and lipid mediators (35). Importantly, eosinophils have the capacity to adhere to activated endothelial cells, to leave the bloodstream and to concentrate at the site of allergic inflammation (38). These cells and their mediators are found in airway tissue and sputum of patients with asthma (39). In addition, human eosinophils play a major role in the modulation of the functions of a wide spectrum of cells of the innate and adaptive immune system, including subsets of lymphocytes, macrophages, mast cells, basophils, neutrophils, dendritic and plasma cells, and platelets (Figure 1).

\section{IL-5 AND ITS RECEPTOR}

Interleukin-5 is the most important growth, differentiation, and activating factor for human eosinophils (35). This cytokine is a dimeric protein with a 4-helix bundle motif, and it acts on target cells by binding to its specific IL- 5 receptor (IL-5R), which consists of an IL-5 receptor $\alpha$ (IL-5R $\alpha$ ) subunit (IL-5R $\alpha$ ) and a common receptor $\beta$ subunit $(\beta c)(40,41)$. IL-5R $\alpha$ specifically binds IL- 5 and induces the recruitment of $\beta c$ to IL-5R (42). The $\beta c$ subunit is a signal-transducing molecule shared with two receptors for monomeric cytokines, IL-3, and granulocyte-macrophage colony-stimulating (GM-CSF) (40). Figure 2 illustrates that IL-5 is mainly produced by ILC2, Th2 cells, mast cells, invariant natural killer cells (NK T cells), and eosinophils themselves (43). Although IL-5 is crucial for maturation and activation of human eosinophils (44), there is evidence that GM-CSF and IL-3 can function as eosinophil survival factors (45). Recent evidence indicates that IL-5, along with GM-CSF and IL-3, mediates eosinophil cellular survival by NF-Kb-induced $\mathrm{Bcl}-\mathrm{x}_{\mathrm{l}}$, which inhibits apoptosis (46). Interestingly, substantial levels of eosinophils remain after IL-5 neutralization or genetic deletion, suggesting that there are alternative pathways for promoting eosinophilia (47). Finally, IL-3 triggers prolonged signaling through activation of ribosomal protein S6 in human eosinophils providing new insight into the 


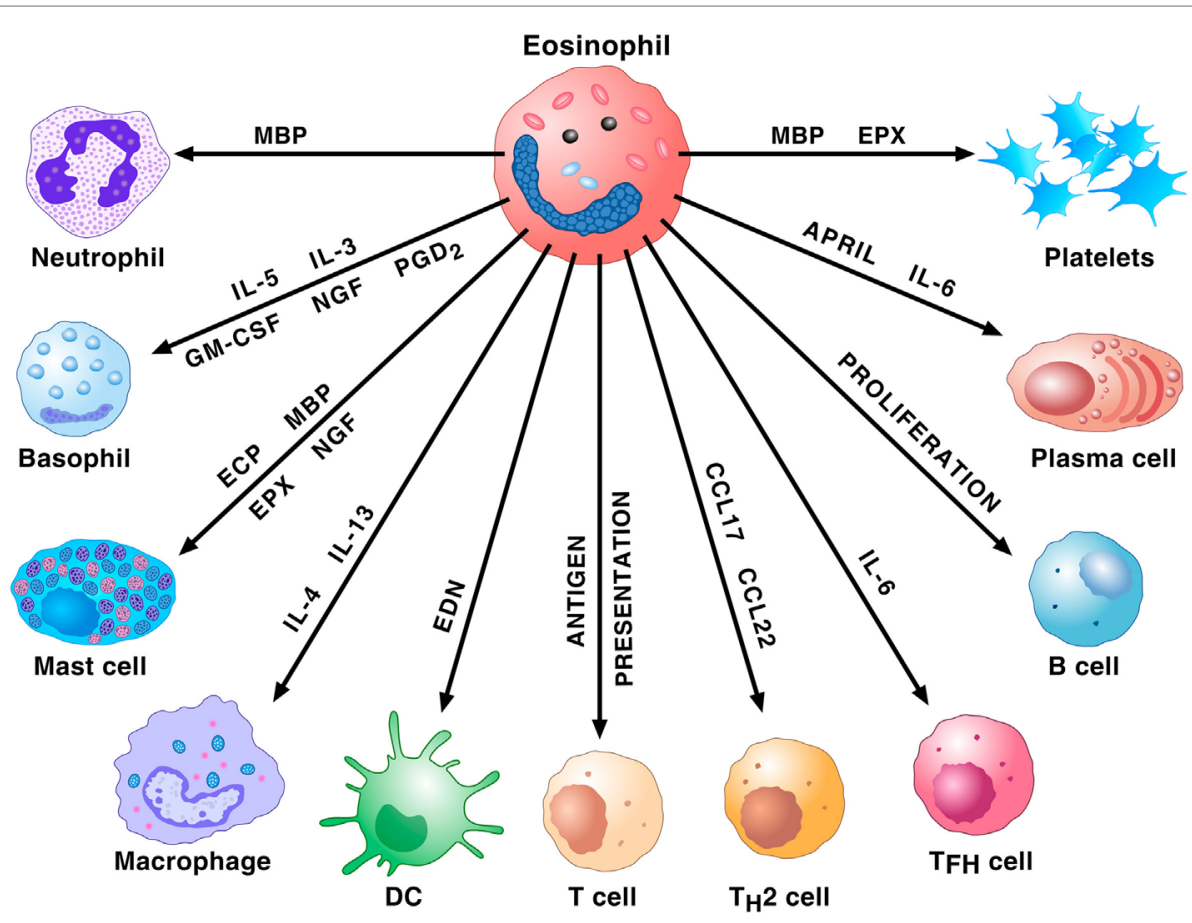

FIGURE 1 | Eosinophils and their mediators activate or modulate a plethora of cells of the innate and adaptive immune system. Major basic protein (MBP) activates human neutrophils. Eosinophils prime/activate human basophils and mast cells through the release of cytokines [interleukin-5 (IL-5), interleukin-5 (IL-3), granulocyte-macrophage colony-stimulating (GM-CSF), NGF, and $\mathrm{PGD}_{2}$ ] or cationic proteins [eosinophil cationic protein (ECP), MBP, and eosinophil peroxidase (EPX)]. IL-4 and IL-13 favor M2 polarization of macrophages. EDN promotes the migration, maturation, and activation of dendritic cells (DCs). Eosinophils can act as antigen-presenting cells to initiate T cell responses and contribute to the recruitment of Th2 cells by producing the chemokines CCL17 and CCL22. These cells also favor T follicular helper (Tfh) cell maturation via the production of IL-6. Eosinophils promote B cell proliferation through an unknown mechanism. Eosinophils prime B cells and sustain plasma cells through the production of APRIL and IL-6. MBP and EPX induce platelet aggregation.

mechanisms underlined differential activation of eosinophils by IL-5 and IL-3 (48).

Whereas IL-5 is crucial for supporting mature eosinophils, the signals that support earlier eosinophil lineage events are less defined. Recent evidence indicates that IL-33 is required for basal eosinophil homeostasis (49) suggesting that this cytokine, through activation of ILC2 and their production of IL-5, plays a key role in promoting eosinophilopoiesis in response to allergen exposure (50).

Based on the previous observations, during the last decades targeting IL-5 or IL-5R $\alpha$ appeared an interesting approach to the treatment of patients with severe eosinophilic asthma and hypereosinophilic-associated disorders $(35,51)$. Two humanized monoclonal antibodies directed against IL-5 [mepolizumab (proposed trade name Nucala; GSK) and reslizumab (proposed trade name Cinqair; Teva)] have provided an opportunity to investigate the role of this pathway in defining therapy of severe eosinophilic asthma $(44,51)$. Moreover, benralizumab (MedImmune/AstraZeneca), a humanized monoclonal antibody directed against the $\alpha$-chain of the IL-5R, present on eosinophils and basophils (52), demonstrated efficacy and safety in adult patients with severe eosinophilic asthma $(53,54)$.

Reslizumab, previously known as Sch 55700, is a humanized, neutralizing anti-IL-5 antibody. Sch 55700 was humanized using complementary determining region drafting technology from a rat monoclonal antibody with a $K_{\mathrm{d}}$ of $53 \mathrm{pM}$ against human IL-5 (55). The humanized antibody (reslizumab) retains the potency of the parent antibody, blocks IL-5R binding, and inhibits IL-5-induced cell proliferation (56). Reslizumab binds to a small region corresponding to amino acids 89-92 of IL-5 that are critical for binding to IL-5R $\alpha$ (55) (Figure 2).

An initial multicenter study evaluated in a randomized, double-blind the effect of a single dose of i.v. reslizumab in a small group of severe asthmatics. The dose of $1 \mathrm{mg} / \mathrm{kg}$ produced a reduction in eosinophil counts but did not improve lung functions or symptom score (57). A subsequent multicenter, randomized, double-blind, and placebo-controlled study in poorly controlled asthmatics and sputum eosinophils $\geq 3 \%$ demonstrated that reslizumab $(3 \mathrm{mg} / \mathrm{kg}$ i.v. every 4 weeks per four doses) reduced sputum eosinophils and improved airway function particularly in patients with nasal polyps (58). In two duplicated, multicenter, double-blind, parallel group, randomized, and placebo-controlled trials, a large number of patients were treated with reslizumab ( $3 \mathrm{mg} / \mathrm{kg}$ i.v. every 4 weeks per 13 doses). This monoclonal antibody reduced asthma exacerbations and improved $\mathrm{FEV}_{1}$ (59).

A phase III study further characterized the efficacy and safety of reslizumab (3 mg/kg i.v. every 4 weeks per four doses) in 


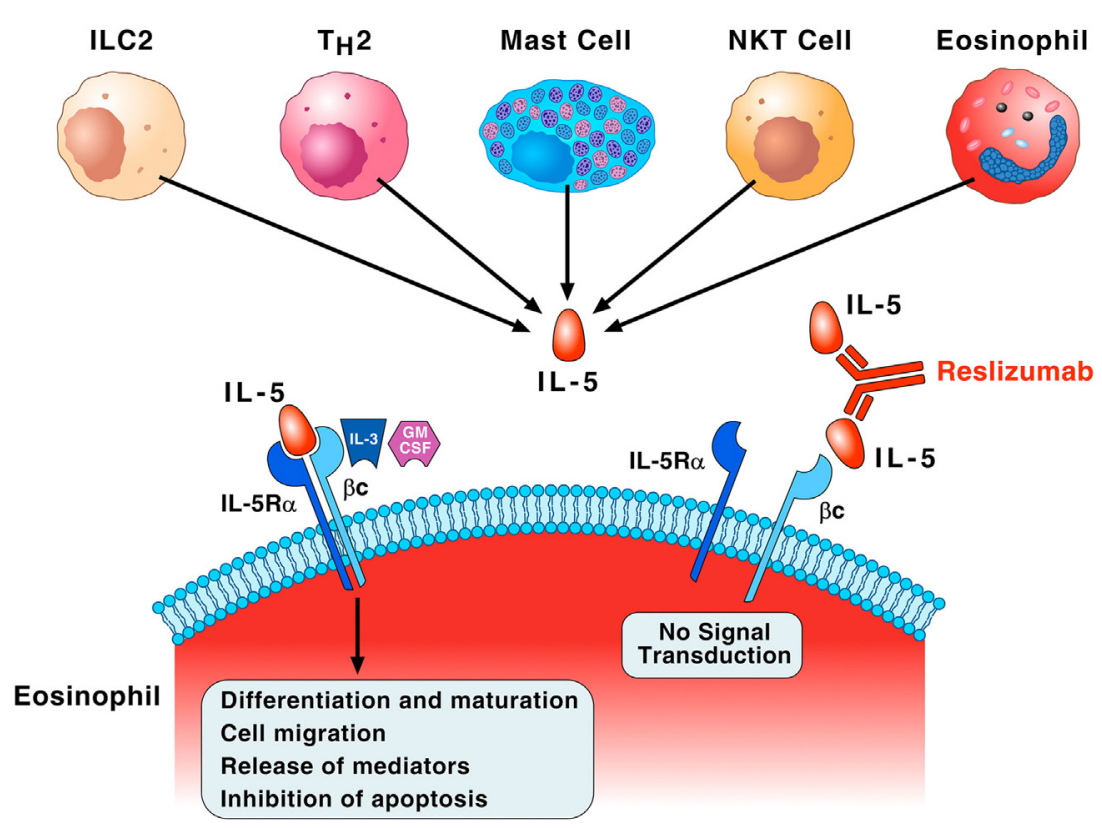

FIGURE 2 | Interleukin-5 (IL-5) plays a fundamental role in the growth, maturation, and activation of human eosinophils. Group 2 innate lymphoid cell (ILC2), Th2 cells, mast cells, natural killer cells (NK T cells), and eosinophils themselves produce IL-5. This cytokine specifically binds to IL-5 receptor $\alpha$ (IL-5R $\alpha$ ) and recruits the $\beta c$ subunit on the membrane of eosinophils. The $\beta c$ subunit is the signal-transducing molecule shared with IL- 3 and granulocyte-macrophage colony-stimulating (GM-CSF). This IL-5R $\alpha / \beta \mathrm{c}$ interaction leads to a series of biochemical events that control eosinophil differentiation and maturation in the bone marrow, cell migration to the site of allergic inflammation, the release of pro-inflammatory mediators, and inhibition of apoptosis. IL-3 and presumably GM-CSF, through binding to the $\beta \mathrm{c}$ of IL-5 receptor, can also function as eosinophil survival factors. Reslizumab binds with high affinity ( $K_{d}$ of approximately 50 pM) to amino acids 89-92 of human IL-5 that are critical for binding to IL-5R $\alpha$, resulting in inhibition of eosinophil maturation and activation.

patients aged 12-75 years with asthma inadequately controlled by ICS and with a blood eosinophil count $\geq 400$ cells/ $\mu \mathrm{L}(60)$. Reslizumab improved lung function $\left(\mathrm{FEV}_{1}\right)$, asthma control and symptoms, and quality of life (asthma control questionnaire and asthma quality of life questionnaire) and was well-tolerated. In another phase III study, the efficacy of reslizumab (3 mg/ kg i.v. every 4 weeks per four doses) was evaluated in patients with poorly controlled asthma, particularly those with blood eosinophils $\leq 400$ cells/ $\mu \mathrm{L}$ (61). Interestingly, in the latter group of patients, clinically meaningful effects on lung functions (FEV1) and symptoms were not seen in patients unselected for baseline eosinophils.

The two latter studies emphasize the importance of selecting patients based on the number of eosinophils $(\geq 400 \mu \mathrm{L})$ in peripheral blood. Thus, the use of blood eosinophils as a baseline biomarker could help to select patients who are likely to achieve more benefits in asthma control with reslizumab. Raised blood eosinophil count has recently been described as a useful biomarker to assess patients with eosinophilic asthma $(53,54$, 60-64) and as a predictor of response to glucocorticoids (65). However, it should be emphasized that blood eosinophil counts do not accurately predict sputum eosinophils in severe asthmatics (66). Moreover, there is no correlation between sputum and blood eosinophil counts in severe glucocorticoid-dependent asthmatics (67).

In March 2016, the Food and Drug Administration concluded that reslizumab has an adequate safety profile and demonstrates the efficacy in treating severe eosinophilic asthma in adults. The approved dosage regimen is $3 \mathrm{mg} / \mathrm{kg}$ i.v. over $20-50 \mathrm{~min}$ every 4 weeks for patients aged $\geq 18$ years.

\section{CONCLUDING REMARKS}

Several studies have demonstrated that the i.v. administration of reslizumab is well-tolerated in adult patients with severe eosinophilic asthma up to 1 year. Recent evidences demonstrate that eosinophils play a role in cancer rejection $(68,69)$ and that several hematologic and tissue cancers can be associated with eosinophilia (70). In addition, it has been suggested that "targeted anti-eosinophilic strategies may unmask or even accelerate progression" of certain tumors in few patients with hypereosinophilic syndrome (71). Therefore, future surveillance and "real-life" studies will be needed to further confirm the safety of reslizumab in long-term treatment of patients with severe eosinophilic asthma. Recent studies have demonstrated the safety and efficacy of two monoclonal antibodies anti-IL-5-mepolizumab $(63,64)$ and reslizumab $(59-61)$ - and of anti-IL-5 $\mathrm{Ra}(53,54)$ in the treatment of adult patients with severe eosinophilic asthma. Different inclusion criteria (e.g., blood eosinophil count $\geq 300 \mathrm{vs} \geq 400 / \mathrm{mL}$ ) and routes of administration (s.c. vs i.v.) of anti IL-5/anti-IL-5 $\mathrm{Ra}$ preclude a quantitative comparison of the results obtained in different trials.

A major advance in the development of a precision medicine approach for the treatment of severe asthma is the ability to select 
the appropriate patients. Ideally, patients should be selected by an easily measured biomarker. The studies with reslizumab treatment for severe eosinophilic asthma demonstrate that the blood eosinophil count $(\geq 400 \mu \mathrm{L})$ appears closely associated with a clinical response in adult patients (59-61). Therefore, the age of precision medicine has arrived for the subset of severe asthmatics with an eosinophil-driven phenotype using anti-IL-5 therapy with reslizumab [(72) (posted online)].

Future studies should evaluate the safety and efficacy of reslizumab in children and in patients with other eosinophil-driven diseases. Preliminary studies in patients with nasal polyps (73) and in children and adolescents with eosinophilic esophagitis (74) demonstrated that reslizumab reduced tissue eosinophils without improvement in symptoms. Additional studies should investigate the optimal dose and strategy of reslizumab treatment in these and other eosinophil-driven diseases (e.g., atopic dermatitis and EGPA).

Future studies should also evaluate the outcome of patients with severe eosinophilic asthma after discontinuation of reslizumab therapy. A preliminary study reported that cessation of mepolizumab in patients with eosinophilic asthma resulted in a rapid increase of blood eosinophils followed by gradual increase in asthma symptoms and exacerbations (75).

\section{REFERENCES}

1. Fahy JV. Type 2 inflammation in asthma - present in most, absent in many. Nat Rev Immunol (2015) 15:57-65. doi:10.1038/nri3786

2. Holgate ST. Innate and adaptive immune responses in asthma. Nat Med (2012) 18:673-83. doi:10.1038/nm.2731

3. Chung KF, Wenzel SE, Brozek JL, Bush A, Castro M, Sterk PJ, et al. International ERS/ATS guidelines on definition, evaluation and treatment of severe asthma. Eur Respir J (2014) 43:343-73. doi:10.1183/09031936.00202013

4. To T, Stanojevic S, Moores G, Gershon AS, Bateman ED, Cruz AA, et al. Global asthma prevalence in adults: findings from the cross-sectional world health survey. BMC Public Health (2012) 12:204. doi:10.1186/1471-2458-12-204

5. Chanez P, Humbert M. Asthma: still a promising future? Eur Respir Rev (2014) 23:405-7. doi:10.1183/09059180.00009614

6. Croisant S. Epidemiology of asthma: prevalence and burden of disease. $A d v$ Exp Med Biol (2014) 795:17-29. doi:10.1007/978-1-4614-8603-9_2

7. Fernandes AG, Souza-Machado C, Coelho RC, Franco PA, Esquivel RM, Souza-Machado A, et al. Risk factors for death in patients with severe asthma. J Bras Pneumol (2014) 40:364-72. doi:10.1590/S1806-37132014000400003

8. Bahadori K, Doyle-Waters MM, Marra C, Lynd L, Alasaly K, Swiston J, et al. Economic burden of asthma: a systematic review. BMC Pulm Med (2009) 9:24. doi:10.1186/1471-2466-9-24

9. Van Eerdewegh P, Little RD, Dupuis J, Del Mastro RG, Falls K, Simon J, et al. Association of the ADAM33 gene with asthma and bronchial hyperresponsiveness. Nature (2002) 418:426-30. doi:10.1038/nature00878

10. Marone G, Triggiani M, de Paulis A. Mast cells and basophils: friends as well as foes in bronchial asthma? Trends Immunol (2005) 26:25-31. doi:10.1016/j. it.2004.10.010

11. Barton SJ, Koppelman GH, Vonk JM, Browning CA, Nolte IM, Stewart CE, et al. PLAUR polymorphisms are associated with asthma, PLAUR levels, and lung function decline. J Allergy Clin Immunol (2009) 123:1391-400. e17. doi:10.1016/j.jaci.2009.03.014

12. Kim HY, DeKruyff RH, Umetsu DT. The many paths to asthma: phenotype shaped by innate and adaptive immunity. Nat Immunol (2010) 11:577-84. doi:10.1038/ni.1892

13. Schauberger EM, Ewart SL, Arshad SH, Huebner M, Karmaus W, Holloway JW, et al. Identification of ATPAF1 as a novel candidate gene for asthma in children. J Allergy Clin Immunol (2011) 128:753-760e711. doi:10.1016/j. jaci.2011.04.058
This interesting observation emphasizes the importance of maintaining suppression of eosinophilic inflammation in severe asthmatics.

Targeted therapy with reslizumab appears to be effective and safe in the treatment of adults with severe eosinophilic asthma and represents one step closer to precision medicine.

\section{AUTHOR CONTRIBUTIONS}

All authors listed have made substantial, direct, and intellectual contribution to the work and approved it for publication.

\section{ACKNOWLEDGMENTS}

The authors apologize to the many authors who have contributed importantly to this field, whose work has not been cited due to space and citation restrictions.

\section{FUNDING}

This work was supported in part by grants from Regione Campania CISI-Lab, CRËME Project, TIMING Project, and ARMIA (Associazione Ricerca Malattie Immunologiche e Allergiche).

14. Anderson GP. Endotyping asthma: new insights into key pathogenic mechanisms in a complex, heterogeneous disease. Lancet (2008) 372:1107-19. doi:10.1016/S0140-6736(08)61452-X

15. Corren J. Asthma phenotypes and endotypes: an evolving paradigm for classification. Discov Med (2013) 15:243-9.

16. Green RH, Brightling CE, Woltmann G, Parker D, Wardlaw AJ, Pavord ID. Analysis of induced sputum in adults with asthma: identification of subgroup with isolated sputum neutrophilia and poor response to inhaled corticosteroids. Thorax (2002) 57:875-9. doi:10.1136/thorax.57.10.875

17. Wenzel SE. Asthma phenotypes: the evolution from clinical to molecular approaches. Nat Med (2012) 18:716-25. doi:10.1038/nm.2678

18. Choy DF, Hart KM, Borthwick LA, Shikotra A, Nagarkar DR, Siddiqui D, et al. TH2 and TH17 inflammatory pathways are reciprocally regulated in asthma. Sci Transl Med (2015) 7:301ra129. doi:10.1126/scitranslmed. aab3142

19. Mukherjee M, Svenningsen S, Nair P. Glucocortiosteroid subsensitivity and asthma severity. Curr Opin Pulm Med (2017) 23:78-88. doi:10.1097/ MCP.0000000000000337

20. Matthews JG, Ito K, Barnes PJ, Adcock IM. Defective glucocorticoid receptor nuclear translocation and altered histone acetylation patterns in glucocorticoid-resistant patients. J Allergy Clin Immunol (2004) 113:1100-8. doi:10.1016/j.jaci.2004.03.018

21. Hew M, Bhavsar P, Torrego A, Khorasani N, Barnes PJ, Adcock I, et al. Relative corticosteroid insensitivity of peripheral blood mononuclear cells in severe asthma. Am J Respir Crit Care Med (2006) 174:134-41. doi:10.1164/ rccm.200512-1930OC

22. Goleva E, Li LB, Eves PT, Strand MJ, Martin RJ, Leung DY. Increased glucocorticoid receptor beta alters steroid response in glucocorticoid-insensitive asthma. Am J Respir Crit Care Med (2006) 173:607-16. doi:10.1164/ rccm.200507-1046OC

23. Kobayashi Y, Mercado N, Barnes PJ, Ito K. Defects of protein phosphatase 2A causes corticosteroid insensitivity in severe asthma. Plos One (2011) 6(12):e27627. doi:10.1371/journal.pone.0027627

24. Chang PJ, Bhavsar PK, Michaeloudes C, Khorasani N, Chung KF. Corticosteroid insensitivity of chemokine expression in airway smooth muscle of patients with severe asthma. J Allergy Clin Immunol (2012) 130:877.e-85.e. doi:10.1016/j.jaci.2012.07.017

25. Chachi L, Shikotra A, Duffy SM, Tliba O, Brightling C, Bradding P, et al. Functional KCa3.1 channels regulate steroid insensitivity in bronchial 
smooth muscle cells. J Immunol (2013) 191:2624-36. doi:10.4049/jimmunol. 1300104

26. Perry MM, Baker JE, Gibeon DS, Adcock IM, Chung KF. Airway smooth muscle hyperproliferation is regulated by microRNA-221 in severe asthma. Am J Respir Cell Mol Biol (2014) 50:7-17. doi:10.1165/rcmb.20130067OC

27. Chang PJ, Michaeloudes C, Zhu J, Shaikh N, Baker J, Chung KF, et al. Impaired nuclear translocation of the glucocorticoid receptor in corticosteroid-insensitive airway smooth muscle in severe asthma. Am J Respir Crit Care Med (2015) 191:54-62. doi:10.1164/rccm.201402-0314OC

28. Chachi L, Abbasian M, Gavrila A, Tliba O, Bradding P, Wardlaw AJ, et al. Protein phosphatase 5 mediates corticosteroid insensitivity in airway smooth muscle in patients with severe asthma. Allergy (2017) 72:126-36. doi:10.1111/ all.13003

29. Holloway JW, Arshad SH, Holgate ST. Using genetics to predict the natural history of asthma? J Allergy Clin Immunol (2010) 126:200-209; quiz 210-201. doi:10.1016/j.jaci.2010.06.006

30. Meyers DA, Bleecker ER, Holloway JW, Holgate ST. Asthma genetics and personalised medicine. Lancet Respir Med (2014) 2:405-15. doi:10.1016/ S2213-2600(14)70012-8

31. Zhang JY, Wenzel SE. Tissue and BAL based biomarkers in asthma. Immunol Allergy Clin North Am (2007) 27:623-632;vi. doi:10.1016/j.iac.2007. 09.003

32. Price D, Wilson AM, Chisholm A, Rigazio A, Burden A, Thomas M, et al. Predicting frequent asthma exacerbations using blood eosinophil count and other patient data routinely available in clinical practice. J Asthma Allergy (2016) 9:1-12. doi:10.2147/JAA.S97973

33. Belda J, Parameswaran K, Lemiere C, Kamada D, O'Byrne PM, Hargreave FE. Predictors of loss of asthma control induced by corticosteroid withdrawal. Can Respir J (2006) 13:129-33. doi:10.1155/2006/189127

34. Vaglio A, Buzio C, Zwerina J. Eosinophilic granulomatosis with polyangiitis (Churg-Strauss): state of the art. Allergy (2013) 68:261-73. doi:10.1111/ all.12088

35. Varricchi G, Bagnasco D, Borriello F, Heffler E, Canonica GW. Interleukin-5 pathway inhibition in the treatment of eosinophilic respiratory disorders: evidence and unmet needs. Curr Opin Allergy Clin Immunol (2016) 16:186-200. doi:10.1097/ACI.0000000000000251

36. Detoraki A, Di Capua L, Varricchi G, Genovese A, Marone G, Spadaro G. Omalizumab in patients with eosinophilic granulomatosis with polyangiitis: a 36-month follow-up study. J Asthma (2016) 53:201-6. doi:10.3109/0277 0903.2015.1081700

37. Kay AB. The early history of the eosinophil. Clin Exp Allergy (2015) 45:575-82. doi:10.1111/cea.12480

38. Furuta GT, Atkins FD, Lee NA, Lee JJ. Changing roles of eosinophils in health and disease. Ann Allergy Asthma Immunol (2014) 113:3-8. doi:10.1016/j. anai.2014.04.002

39. Sehmi R, Smith SG, Kjarsgaard M, Radford K, Boulet LP, Lemiere C, et al. Role of local eosinophilopoietic processes in the development of airway eosinophilia in prednisone-dependent severe asthma. Clin Exp Allergy (2016) 46:793-802. doi:10.1111/cea.12695

40. Broughton SE, Nero TL, Dhagat U, Kan WL, Hercus TR, Tvorogov D, et al. The betac receptor family - structural insights and their functional implications. Cytokine (2015) 74:247-58. doi:10.1016/j.cyto.2015.02.005

41. Kusano S, Kukimoto-Niino M, Hino N, Ohsawa N, Ikutani M, Takaki S, et al. Structural basis of interleukin- 5 dimer recognition by its alpha receptor. Protein Sci (2012) 21:850-64. doi:10.1002/pro.2072

42. Tavernier J, Devos R, Cornelis S, Tuypens T, Van der Heyden J, Fiers W, et al. A human high affinity interleukin-5 receptor (IL5R) is composed of an IL5-specific alpha chain and a beta chain shared with the receptor for GM-CSF. Cell (1991) 66:1175-84. doi:10.1016/0092-8674(91)90040-6

43. Nussbaum JC, Van Dyken SJ, von Moltke J, Cheng LE, Mohapatra A, Molofsky $\mathrm{AB}$, et al. Type 2 innate lymphoid cells control eosinophil homeostasis. Nature (2013) 502:245-8. doi:10.1038/nature12526

44. Varricchi G, Canonica GW. The role of interleukin 5 in asthma. Expert Rev Clin Immunol (2016) 12:903-5. doi:10.1080/1744666X.2016.1208564

45. Rothenberg ME, Owen WF Jr, Silberstein DS, Soberman RJ, Austen KF, Stevens RL. Eosinophils cocultured with endothelial cells have increased survival and functional properties. Science (1987) 237:645-7. doi:10.1126/ science.3110954
46. Schwartz C, Willebrand R, Huber S, Rupec RA, Wu D, Locksley R, et al. Eosinophil-specific deletion of IkappaBalpha in mice reveals a critical role of NF-kappaB-induced Bcl-xL for inhibition of apoptosis. Blood (2015) 125:3896-904. doi:10.1182/blood-2014-10-607788

47. Fulkerson PC, Schollaert KL, Bouffi C, Rothenberg ME. IL-5 triggers a cooperative cytokine network that promotes eosinophil precursor maturation. J Immunol (2014) 193:4043-52. doi:10.4049/jimmunol.1400732

48. Esnault S, Kelly EA, Shen ZJ, Johansson MW, Malter JS, Jarjour NN. IL-3 maintains activation of the p90S6K/RPS6 pathway and increases translation in human eosinophils. J Immunol (2015) 195:2529-39. doi:10.4049/ jimmunol.1500871

49. Johnston LK, Hsu CL, Krier-Burris RA, Chhiba KD, Chien KB, McKenzie A, et al. IL-33 precedes IL-5 in regulating eosinophil commitment and is required for eosinophil homeostasis. J Immunol (2016) 197:3445-53. doi:10.4049/jimmunol.1600611

50. Anderson EL, Kobayashi T, Iijima K, Bartemes KR, Chen CC, Kita H. IL-33 mediates reactive eosinophilopoiesis in response to airborne allergen exposure. Allergy (2016) 71:977-88. doi:10.1111/all.12861

51. Varricchi G, Bagnasco D, Ferrando M, Puggioni F, Passalacqua G, Canonica GW. Mepolizumab in the management of severe eosinophilic asthma in adults: current evidence and practical experience. Ther Adv Respir Dis (2017) 11:40-5. doi:10.1177/1753465816673303

52. Kolbeck R, Kozhich A, Koike M, Peng L, Andersson CK, Damschroder MM, et al. MEDI-563, a humanized anti-IL-5 receptor alpha mAb with enhanced antibody-dependent cell-mediated cytotoxicity function. J Allergy Clin Immunol (2010) 125(6):1344-53.e2. doi:10.1016/j.jaci.2010.04.004

53. Bleecker ER, FitzGerald JM, Chanez P, Papi A, Weinstein SF, Barker P, et al. Efficacy and safety of benralizumab for patients with severe asthma uncontrolled with high-dosage inhaled corticosteroids and long-acting beta2-agonists (SIROCCO): a randomised, multicentre, placebo-controlled phase 3 trial. Lancet (2016) 388(10056):2115-27. doi:10.1016/ S0140-6736(16)31324-1

54. FitzGerald JM, Bleecker ER, Nair P, Korn S, Ohta K, Lommatzsch M, et al. Benralizumab, an anti-interleukin-5 receptor alpha monoclonal antibody, as add-on treatment for patients with severe, uncontrolled, eosinophilic asthma (CALIMA): a randomised, double-blind, placebo-controlled phase 3 trial. Lancet (2016) 388(10056):2128-41. doi:10.1016/S0140-6736(16) 31322-8

55. Zhang J, Kuvelkar R, Murgolo NJ, Taremi SS, Chou CC, Wang P, et al. Mapping and characterization of the epitope(s) of Sch 55700, a humanized mAb, that inhibits human IL-5. Int Immunol (1999) 11:1935-44. doi:10.1093/ intimm/11.12.1935

56. Egan RW, Athwal D, Bodmer MW, Carter JM, Chapman RW, Chou CC, et al. Effect of Sch 55700, a humanized monoclonal antibody to human interleukin-5, on eosinophilic responses and bronchial hyperreactivity. Arzneimittelforschung (1999) 49:779-90. doi:10.1055/s-0031-1300502

57. Kips JC, O’Connor BJ, Langley SJ, Woodcock A, Kerstjens HA, Postma DS, et al. Effect of SCH55700, a humanized anti-human interleukin-5 antibody, in severe persistent asthma: a pilot study. Am J Respir Crit Care Med (2003) 167:1655-9. doi:10.1164/rccm.200206-525OC

58. Castro M, Mathur S, Hargreave F, Boulet LP, Xie F, Young J, et al. Reslizumab for poorly controlled, eosinophilic asthma: a randomized, placebo-controlled study. Am J Respir Crit Care Med (2011) 184:1125-32. doi:10.1164/ rccm.201103-0396OC

59. Castro M, Zangrilli J, Wechsler ME, Bateman ED, Brusselle GG, Bardin P, et al. Reslizumab for inadequately controlled asthma with elevated blood eosinophil counts: results from two multicentre, parallel, double-blind, randomised, placebo-controlled, phase 3 trials. Lancet Respir Med (2015) 3:355-66. doi:10.1016/S2213-2600(15)00042-9

60. Bjermer L, Lemiere C, Maspero J, Weiss S, Zangrilli J, Germinaro M. Reslizumab for inadequately controlled asthma with elevated blood eosinophil levels: a randomized phase 3 study. Chest (2016) 150:789-98. doi:10.1016/j.chest.2016.03.032

61. Corren J, Weinstein S, Janka L, Zangrilli J, Garin M. Phase 3 study of reslizumab in patients with poorly controlled asthma: effects across a broad range of eosinophil counts. Chest (2016) 150:799-810. doi:10.1016/j. chest.2016.03.018

62. Pavord ID, Korn S, Howarth P, Bleecker ER, Buhl R, Keene ON, et al. Mepolizumab for severe eosinophilic asthma (DREAM): a multicentre, 
double-blind, placebo-controlled trial. Lancet (2012) 380:651-9. doi:10.1016/ S0140-6736(12)60988-X

63. Bel EH, Wenzel SE, Thompson PJ, Prazma CM, Keene ON, Yancey SW, et al. Oral glucocorticoid-sparing effect of mepolizumab in eosinophilic asthma. N Engl J Med (2014) 371:1189-97. doi:10.1056/NEJMoa1403291

64. Ortega HG, Liu MC, Pavord ID, Brusselle GG, FitzGerald JM, Chetta A, et al. Mepolizumab treatment in patients with severe eosinophilic asthma. N Engl J Med (2014) 371:1198-207. doi:10.1056/NEJMoa1403290

65. Tran TN, Khatry DB, Ke X, Ward CK, Gossage D. High blood eosinophil count is associated with more frequent asthma attacks in asthma patients. Ann Allergy Asthma Immunol (2014) 113:19-24. doi:10.1016/j.anai.2014.04.011

66. Hastie AT, Moore WC, Li H, Rector BM, Ortega VE, Pascual RM, et al. Biomarker surrogates do not accurately predict sputum eosinophil and neutrophil percentages in asthmatic subjects. J Allergy Clin Immunol (2013) 132:72-80. doi:10.1016/j.jaci.2013.03.044

67. Mukherjee M, Nair P. Blood or sputum eosinophils to guide asthma therapy? Lancet Respir Med (2015) 3:824-5. doi:10.1016/S2213-2600(15)00419-1

68. Carretero R, Sektioglu IM, Garbi N, Salgado OC, Beckhove P, Hammerling GJ. Eosinophils orchestrate cancer rejection by normalizing tumor vessels and enhancing infiltration of CD8(+) T cells. Nat Immunol (2015) 16:609-17. doi:10.1038/ni.3159

69. Legrand F, Driss V, Delbeke M, Loiseau S, Hermann E, Dombrowicz D, et al. Human eosinophils exert TNF-alpha and granzyme A-mediated tumoricidal activity toward colon carcinoma cells. J Immunol (2010) 185:7443-51. doi:10.4049/jimmunol.1000446

70. Simson L, Ellyard JI, Dent LA, Matthaei KI, Rothenberg ME, Foster PS, et al. Regulation of carcinogenesis by IL-5 and CCL11: a potential role for eosinophils in tumor immune surveillance. J Immunol (2007) 178:4222-9. doi:10.4049/jimmunol.178.7.4222

71. Roufosse F, de Lavareille A, Schandene L, Cogan E, Georgelas A, Wagner L, et al. Mepolizumab as a corticosteroid-sparing agent in lymphocytic variant hypereosinophilic syndrome. J Allergy Clin Immunol (2010) 126:828-835e823. doi:10.1016/j.jaci.2010.06.049

72. Ferrando M, Bagnasco D, Varricchi G, Bernardi S, Bragantini A, Passalacqua G, et al. Personalized medicine in allergy. Allergy Asthma Immunol Res (2017) 9:15-24. doi:10.4168/aair.2017.9.1.15

73. Gevaert P, Lang-Loidolt D, Lackner A, Stammberger H, Staudinger H, Van Zele T, et al. Nasal IL-5 levels determine the response to anti-IL-5 treatment in patients with nasal polyps. J Allergy Clin Immunol (2006) 118:1133-41. doi:10.1016/j.jaci.2006.05.031

74. Spergel JM, Rothenberg ME, Collins MH, Furuta GT, Markowitz JE, Fuchs G III, et al. Reslizumab in children and adolescents with eosinophilic esophagitis: results of a double-blind, randomized, placebo-controlled trial. J Allergy Clin Immunol (2012) 129:.e1-3. doi:10.1016/j.jaci.2011. 11.044

75. Haldar P, Brightling CE, Singapuri A, Hargadon B, Gupta S, Monteiro W, et al. Outcomes after cessation of mepolizumab therapy in severe eosinophilic asthma: a 12-month follow-up analysis. J Allergy Clin Immunol (2014) 133:921-3. doi:10.1016/j.jaci.2013.11.026

Conflict of Interest Statement: The authors declare that the research was conducted in the absence of any commercial or financial relationships that could be construed as a potential conflict of interest.

Copyright () 2017 Varricchi, Senna, Loffredo, Bagnasco, Ferrando and Canonica. This is an open-access article distributed under the terms of the Creative Commons Attribution License (CC BY). The use, distribution or reproduction in other forums is permitted, provided the original author(s) or licensor are credited and that the original publication in this journal is cited, in accordance with accepted academic practice. No use, distribution or reproduction is permitted which does not comply with these terms. 